\title{
COMMENT
}

\section{THE SIGNIFICANCE OF AL GORE'S PURPORTED HYPOCRISY}

Al Gore's An Inconvenient Truth closes with a section titled, "So here's what you personally can do to solve the climate crisis" (An Inconvenient Truth [Emmaus, Pa.: Rodale Press, 2006], p. 305). In it, Gore proposes that we take individual responsibility. He advises that we reduce emissions from home energy use and reduce air travel. Gore has received a good deal of criticism for this advice - namely, that he himself does not follow it. Rush Limbaugh was already making the accusation in 1993: "Al Gore thinks the automobile is one of the greatest threats to the planet, but he sure as heck travels in one of them-a real gas guzzler, too" (See, I Told You So [New York: Pocket Books, 1993], p. 168). After Gore's documentary won an Oscar in 2007, Gore's hometown paper reported that the Gore home consumes just under \$1,200 of electricity a month on average (Anne Paine, "Group Questions Level of Energy Use at Gore's Home." The Tennessean, 27 February 2007, pp. B1 and B4). The paper was flooded with letters to the editor. For example, "[Gore's] 20-room, eight bathroom Belle Meade home uses more energy a month than the average citizen does a year. Attaboy, Al! And let's not mention his two-year jet tour crisscrossing the globe" (Mark Cook, "Gore's Environmental Efforts Come Up Short," The Tennessean, 3 March 2007, p. A17). The Competitive Enterprise Institute released a series of commercials devoted to Gore's airline flights. One piece ends with the flourish: "Al Gore, in your non-stop travels around the world promoting global warming alarmism. You are talking the talk. . . But are you walking the walk?" (Competitive Enterprise Institute, "An Inconvenient Story," 2006 at http://www.cei.org/pages/co2.cfm. ). In the wake of Gore sharing the 2007 Nobel Peace Prize with the UN's Intergovernmental Panel of Climate Change, one New York Times letter to the editor stated: "Al Gore walks the walk and rides in his atmosphere-polluting private jet to his energy-consuming estate to win a Nobel Prize given for his work on global warming. Sheer hypocrisy" (Bill Steiner, "Al Gore, Nobel Peace Laureate," Letters, New York Times, 12 October 2007).

What hinges on these charges? The writers here leave their conclusions unexpressed, and doing so makes the question of significance hard to determine. Here is one interpretation (call it interpretation $A$ ): Gore advocates that $X$ is to be followed on the theory of global warming $(G)$. Gore does not follow $X$. Therefore, Gore is a hypocrite. Therefore, $X$ is not to be followed and/or $G$ is false or unjustified.

The argument is an attack on Gore's believability - namely, that since he does not follow his own advice, he is not sincere. Since he is not sincere, we have reason to be skeptical of the recommendations he proposes and the theories he argues for. The problem is that this argument suffers from irrelevancy - facts about speakers' inconsistencies do not have to be facts about what they say. These are tu quoque fallacies. They attack Gore the person, and then once they demonstrate his inconsistency, 
leave the audience to infer that his views must be similarly inconsistent (and thereby, false). This conclusion, of course, does not follow. Consider the following exchange, "Smoker Dad":

Dad: You shouldn't smoke, son. Smoking is bad for your health.

Son: But look at you, dad! You smoke, too!

Again, charges of hypocrisy are rarely are combined with explicit conclusions. Perhaps another interpretation of the strategy is appropriate (call it interpretation $B$ ): $S 1$ advocates $X$ be followed on the basis of theory $T$. $S 1$ does not follow $X$. Therefore, $S 1$ is a hypocrite. Therefore, we need to chastise $S 1$, and $S 1$ needs to account for himself or apologize.

This strategy is more in line with what is regularly called a red herring-we were talking about $T$ and $X$, but now we're talking about the $S 1$ 's hypocrisy. What's important has been left behind, and now a painful conversation needs to proceed about the SI's character. SI and SI's apologists will waste their time defending SI's honor while the case for $T$ and $X$ are left aside. Hypocrisy charges are dialectical boondoggles.

Notice now something about "Smoker Dad." Dad holds that his son should stop smoking because it is harmful and addictive. The son's response, either to derail the conversation $(B)$ or to rebut $S 1$ 's argument $(A)$, is that $S 1$ himself smokes. Contrary to what son thinks, the fact that dad has not stopped smoking is all the more evidence that smoking is addictive. Dad is making a critique of a system of habits (smoking), and the fact that dad himself cannot break those habits adds all the more to the poignancy of the critique.

The same goes for Gore criticizing energy use. All too many portray Gore as an environmental crusader (see Limbaugh above), but his proposals are more appropriately assessed as those of a moderate. He proposes incremental changes in our energy consumption, and as such, he will still consume energy and travel in the pathways of the system he criticizes. The pathways may be changed in small ways, but they nevertheless are still worthy of criticism. Consequently, Gore will criticize many forms of energy use, but he will also be guilty of many of the practices he criticizes. He mitigates his transgressions (e.g., energy efficiency and carbon offsets), but they will be transgressions nonetheless. The point here is that someone aware of, highly motivated to avoid, and possessing the best means to redress the hypocrisy charge cannot in the end avoid it. But this is not Gore's failing exclusively, but a testament to how far we have to go to change the system. As with "Smoker Dad," when charged with hypocrisy, Gore should respond, "Exactly!"

Scott Aiken

Department of Philosophy and Religion, Western Kentucky University, 1 Big Red Way, Bowling Green, KY 42101-3576; email: scott.aikin@wku.edu. 